УДК 338.483.13:392.72

\title{
МЕНЕДЖЕР 3 КОРПОРАТИВНОЇ СОЦІАЛЬНОЇ ВІДПОВІДАЛЬНОСТІ У СФЕРІ ГОСТИННОСТІ
}

\section{MANAGER OF CORPORATE SOCIAL RESPONSIBILITY IN THE FIELD OF HOSPITALITY}

\author{
Лешко Христина Сидорівна \\ аспірант, \\ Львівський державний університет фрізичної культури \\ імені Івана Боберського \\ ORCID: https://orcid.org/0000-0002-6383-3873
}

\author{
Leshko Khrystyna \\ Lviv State University of Physical Culture named after I. Boberskyi
}

\begin{abstract}
У статті проаналізовано важливість стратегії КСВ для підприємств індустрії гостинності. Метою дослідження $€$ визначення потреби посади менеджера з КСВ у підприємствах сфрери гостинності. Проаналізовано зону відповідальності менеджера з КСВ. Виділено заробітну плату фрахівця з КСВ у Європі. Розглянуто обов'язки менеджера з КСВ. Виокремлено основні професійні навички менеджера з КСВ, а саме: міжнародні стандарти щодо соціальної звітності; програмні документи щодо соціальної відповідальності; законодавство України та нормативні акти, що регламентують соціальні та трудові відносини; умови та особливості конкурентоспроможного функціонування підприємств різних форм власності; основні напрями маркетингової діяльності; стан та розвиток світової та вітчизняної економіки; напрямки інноваційної та інвестиційної політики; методологію аналізу ринкового середовища на мікроекономічному рівні; взаємозв'язок елементів внутрішнього та оракторів зовнішнього середовища підприємства; екологічну компоненту соціальної відповідальності; законодавство України про охорону навколишнього середовища; перспективи та світові тенденції розвитку технології галузі, психологію управління та конфліктологію; інформаційні технології менеджменту та загальні закономірності взаємодії бізнесу та суспільства; ґенеза концепції корпоративної соціальної відповідальності (КСВ); роль етики бізнесу системі КСВ; етичні стандарти міжнародного бізнесу; склад соціальних інвестицій; механізм економічного регулювання корпоративної соціальної відповідальності; діловодство. Розкрито фракт гендерності у цій професії. Проаналізовано дослідження Європейської асоціації професіоналів 3 питань сталого розвитку за підтримки KPMG та GreenFlex. Визначено основні тенденції розвитку КСВ та важливості навчання фахівців у питаннях соціальної відповідальності. Сорормоване авторське трактування поняття менеджер 3 корпоративної соціальної відповідальності. Проаналізовано стратегію КСВ мережі готелів Нilton. Відповідальних за проєкти та звіти з КСВ у готелі Hilton. Досліджено проєкти та соціальні акції у готелях міжнародної мережі Radisson Hotel Group, а також хто їх розробляє та несе відповідальність за обізнаність працівників та стейкхолдерів у досягнені поставлених цілей.
\end{abstract}

Ключові слова: корпоративна соціальна відповідальність, менеджер з КСВ, соціальні проєкти, розвиток, готель.

В статье проанализированы важность стратегии КСО для предприятий индустрии гостеприимства. Целью исследования является определение потребности должности менеджера по КСО в предприятиях сореры гостеприимства. Проанализированы зону ответственности менеджера по КСО. Выделено заработную плату специалиста по КСО в Европе. Рассмотрены обязанности менеджера по КСО Выделены основные профессиональные навыки менеджера по КСО, а именно: международные стандарты социальной отчетности; программные документы по социальной ответственности; законодательство Украины и нормативные акты, регламентирующие социальные и трудовые отношения; условия и особенности конкурентоспособного функционирования предприятий различных фрорм собственности; основные направления маркетинговой деятельности; состояние и развитие мировой и отечественной экономики направления инновационной и инвестиционной политики; методологию анализа рыночной среды на микроэкономическом уровне; взаимосвязь элементов внутреннего и фракторов внешней среды предприятия; экологическую компоненту социальной ответственности; законодательство Украины об охране окружающей среды; перспективы и мировые тенденции развития технологии отрасли, психологию управления и конфллктологии; информационные технологии менеджмента и общие закономерности взаимодействия 
бизнеса и общества; генезис концепции корпоративной социальной ответственности (КСО) роль этики бизнеса системе КСО этические стандарты международного бизнеса; состав социальных инвестиций; механизм экономического регулирования корпоративной социальной ответственности; делопроизводство. Раскрыто фракт гендерности в этой профессии. Сложившаяся авторская трактовка понятия менеджер по корпоративной социальной ответственности. Проанализированы исследования Европейской ассоциации профессионалов по устойчивому развитию при поддержке KPMG и GreenFlex. Oпределены основные тенденции развития КСО и важности обучения специалистов в вопросах социальной ответственности. Проанализированы стратегию КСО сети отелей Hilton. Ответственных за проекты и отчеты по КСО в отеле Hilton. Исследована проекты и социальные акции в отелях международной сети Radisson Hotel Group, а также кто разрабатывает и несет ответственность за осведомленность работников и стейкхолдеров в достижении поставленных целей.

Ключевые слова: корпоративная социальная ответственность, менеджер по КСО, социальные проекты, развитие, гостиница.

Today, the importance of social responsibility has developed on a large scale around the world. In scientific and business circles the issues of social responsibility of a person, society, state, enterprises are discussed. The trend towards corporate social responsibility came from the west where experience has shown the importance of developing a corporate strategy for social programs. Every year, the management of Ukrainian enterprises increasingly understands that the principles of CSR are not a luxury, but a necessity for the effective operation of business. The CSR manager should be professionally involved in the implementation and development of social programs and the formation of non-financial reports of the organization. Corporate social responsibility is the responsibility of management for their activities, which is reflected in the environment and society. Businesses cannot claim to have corporate social responsibility if their employees work in appalling conditions, as this is primarily a concern for employees. The CSR manager should prepare transparent non-financial reports on internal and external activities, which assess the organization's success in the economic, environmental and social environment, based on dialogue with stakeholders. The largest CSR departments are located in Germany and the United Kingdom, which consist of ten and sometimes more employees. In Germany and the United Kingdom, the state's attention to CSR is very high. These two countries operate within a European model where the concept of CSR is closely linked to the concept of sustainable development. In the European model of CSR, business is as open as possible to dialogue with society. In Germany, the state reduces taxes for CSR companies. In the UK, companies submit weekly non-financial reports to the Times to inform shareholders, employees, partners and society about what social programs are in place at the company. All managers work under a contract of employment, do not own capital and can not manage the company's profits. The freedom of economic choice of managers is limited not only by the terms of the employment contract, job description, legal norms and market conditions, but also by the rules of professional code of ethics. The CSR manager must be competent in his work and know: international standards for social reporting; program documents on social responsibility; legislation of Ukraine and regulations, regulating social and labor relations; conditions and features of competitive functioning of enterprises of different forms of ownership; main directions of marketing activity; state and development of the world and domestic economy; directions of innovation and investment policy; methodology of market environment analysis at the microeconomic level; interrelation of elements of internal and factors of external environment of the enterprise; environmental component of social responsibility; legislation of Ukraine on environmental protection; prospects and world trends in the development of industry technology, management psychology and conflict studies; technologies of management and general laws of interaction of business and society; the genesis of the concept of corporate social responsibility (CSR); the role of business ethics in the CSR system; ethical standards of international business; composition of social investments; mechanism of economic regulation of corporate social responsibility; office work. In Ukraine, CSR retraining is provided by the CSR Development Center, which helps employees develop long-term CSR strategies and teaches non-financial reporting that reflects social activities and more. The European Association of Sustainable Development Professionals, with the support of KPMG and GreenFlex, conducted a study on the profession of CSR and sustainable development managers. This profession is mostly female, and not only in Ukraine: in the world $60 \%$ of positions are held by women. In Ukraine, this figure is almost $85 \%$. The salary of a CSR manager in Europe is 60,000-80,000 euros per year. The highest salaries in Canada and the United States are 90,000 euros (more in dollars). In Ukraine - 13,000 - 17,000 euros per year. Unfortunately there are more women among CSR managers, that are paid less. In the UK, for example, women are paid $£ 52,000$ and men are paid $£ 64,000$. A CSR manager in European countries is in most cases a woman aged 31-50, with experience of 2 to 10 years in this field. Most CSR and sustainable development managers are part of the departments responsible for communications, HR, quality, strategic development and internal audit. A significant number of respondents answered that the area of responsibility of the CSR manager includes: social policy, environmental strategy, as well as the preparation of reports on non-financial indicators for various stakeholders. A striking example of the implementation and development of social programs is the Hilton hotel chain. The CSR strategy and budget are determined by the CEO together with the board of directors and the corporate social responsibility department. Another striking example is the Radisson Blu Hotel hotel chain, which has a large number of long-term CSR projects and charities.

Keywords: corporate social responsibility, CSR manager, social projects, development, hotel. 
Постановка проблеми. Зміни у соціальноекономічних відносинах України зумовлюють формування нових фрункцій управління, а саме використання менеджменту соціального управління. Фахівець 3 корпоративної соціальної відповідальності це нова посада яка отримала назву «менеджер 3 корпоративної соціальної відповідальності» або «менеджер сталого розвитку». Менеджер з корпоративної соціальної відповідальності (далі менеджер з КСВ) - це особа яка відповідальна за соціальні й екологічні проєкти підприємства. В індустрії гостинності проявляється потужне конкурентне середовище, тому у підприємствах які її фрормують зокрема у транспортних, туристичних, готельних та ресторанних об'єктивно виникає необхідність запровадження політики корпоративної соціальної відповідальності. Успішними компаніями $€$ ті у яких корпоративна соціальна відповідальність $€$ однією із пріоритетних корпоративних стратегій розвитку бізнесу, адже КСВ фрормує позитивний імідж та ділову репутацію підприємства, тому важливість фрахівця у цьому напрямку $є$ беззаперечною. В Україні 3 кожним роком все більше керівників підприємств розуміють важливість розвитку соціальної відповідальності, опираючись на позитивний досвід зарубіжних країн де існує не тільки посада менеджера з КСВ, а цілі підрозділи, які відповідальні за різні напрямки КСВ. Ще 10 років тому такої посади не було проте бажання керівників підприємств виходити 3 своїми послугами чи продуктами на міжнародні ринки сприяє її розвитку. Сьогодні в Україні $€$ понад 30 працівників, які посідають посаду менеджер з КСВ, в одиничних випадках це сфрормований окремий підрозділ, наприклад телеканал 1+1, однак здебільшого це працівники PR-відділу або відділу корпоративних комунікацій. Менеджер 3 КСВ це працівник який гарантує отримання прогнозованого позитивного результату від соціальних проєктів підприємства.

Аналіз останніх досліджень та публікацій. Вагомий вклад у дослідженнях та вивчення корпоративної соціальної відповідальності здійснили зарубіжні та вітчизняні науковці: Г. Боуен [1], М. Фрідман [2], К. Девіс [3], А. Керролл [4], Баюра Д.О. [5], Березіна О.Ю. [6], Поважний О.С. [7], Олійник О.О. [8], Зінченко А.Г. [9], Іваницька О.М. [10] та інші. Водночас, в їх працях недостатньо уваги приділяється особливостям підготовки і роботи менеджерів із корпоративної соціальної відповідальності.
Постановка завдання. Метою статті $€$ обґрунтування потреби посади менеджера 3 КСВ у підприємствах сорери гостинності.

Виклад основного матеріалу дослідження. Розглядаючи визначення Міжнародного керівництва соціальної відповідальності (ISO 26000) корпоративна соціальна відповідальність - це відповідальність підприємства за вплив його рішень та дій на суспільство, навколишнє середовище шляхом прозорої та етичної поведінки [11]. На нашу думку, таке визначення $є$ дискусійним оскільки саме по собі підприємство не може нести відповідальності адже воно не виконує ніяких дій, проте керівництво безпосередньо відповідальне за всі свої дії, як позитивні так і негативні. Рівень відповідальності перед суспільством високий у всіх ссрерах діяльності підприємств, якщо це виробництво то відповідальність незмінна на всіх етапах виготовлення, перевезення, використання, утилізації і т.д. Однак рівень відповідальності перед суспільством, працівниками, державою $є$ не меншим у сорері обслуговування. Як у сорері послуг так і у сорері виробництва не може бути зовнішньої корпоративної соціальної відповідальності, якщо керівництво не підтримує внутрішньо соціально відповідальну поведінку, яка починається з персоналу підприємства. У першу чергу це створення сприятливих та безпечних умов праці, медичне страхування працівників, професійний розвиток та відповідна оплата праці. Існує твердження, що міра добробуту та якості роботи працівників відображає ступінь успішності всього підприємства. Тому важливість внутрішньої корпоративної соціальної відповідальності $є$ беззаперечною, адже це не тільки дотримання законодавства, а також швидка реакція на соціальні проблеми, які виникають у працівників, розв'язанням цих питань має займатися менеджер з КСВ. Ефективність підприємства залежить від коесріцієнта плинності кадрів, який має бути оптимальний рівень якого в межах 3-5\%, оскільки втрата цінних кадрів може стати небезпечною для підприємства, а саме якщо профресіонал перейде до конкурента. Адже від внутрішнього середовища підприємства залежить рівень показників продуктивності праці, стабільність розвитку, а також конкурентоспроможність, що формує його позитивний імідж.

Для фрормування позитивного іміджу підприємств сорери гостинності та їх сталих економічних показників керівництво повинне дотримуватися принципів зовнішньої корпоративної соціальної відповідальності на дов- 
гострокові соціальні проєкти. Менеджер 3 КСВ пропонує напрями соціальних проєктів, які мають підтримувати усі працівники підприємства щоб вибудувати свою діяльність в сорері соціальної відповідальності. Напрями зовнішньої КСВ можуть бути спрямовані на різні програми: екологічні, збереження культурної спадщини, розвиток культури, розвиток науки та освіти, благополуччя людей 3 соціально незахищених груп, допомога армії та постраждалим в АТО військовим та інші. Розвиток зовнішньої КСВ це стійкий розвиток, як в межах окремої країни, так і у цілому світі.

Найбільші відділи з КСВ знаходяться у Німеччині та Великобританії, які складаються з двох до десяти працівників. У цих двох країнах увага держави до КСВ $€$ на високому рівні. У Німеччині існує міністерство праці та соціальних справ, яке надає підтримку компаніям у яких діють принципи КСВ. Великі підприємства 100\% здійснюють КСВ. Середні та малі, приблизно 87\% здійснюють соціальну відповідальність перед суспільством. У Німеччині всі компанії, які здійснюють КСВ отримують пільги при оподаткуванні. Концепція корпоративного громадянства в Німеччині має давню історію і традиції ще з XIX століття яка опирається на фрілантропічну відповідальність. У Великобританії $€$ посада міністр 3 КСВ, а також щотижня у газеті «Times» у розділі «Бізнес» публікуються звіти з корпоративної соціальної відповідальності підприємствами які їх здійснюють.

Менеджер з КСВ вибирає напрями соціальних проєктів, та вираховує терміни для реалізації заходу. Перед запуском вибраного соціального проєкту проводиться аналіз виокремленої проблеми, з'ясовується, що вже було зроблено, і що ще можна зробити. А також не менш важливою $є$ співпраця з стейкхолдерами та компетентна передача ідей та переконань працівників підприємства. Менеджер 3 КСВ повинен володіти знаннями про [12]:

- міжнародні та національні стандарти й програмні документи 3 соціальної відповідальності;

- закони та нормативні акти України, що регламентують підприємницьку діяльність, соціальні та трудові відносини;

- концепцію стійкого розвитку;

- основи стратегічного управління;

- теорію аналізу інтересів сторін;

- стан і тенденції розвитку світової та національної економіки;

- методологію аналізу ринкового середовища на мікроекономічному рівні;
- взаємозв'язок між елементами внутрішнього середовища підприємства та ключовими фракторами зовнішнього середовища;

- питання, пов'язані з охороною навколишнього середовища;

- перспективи та світові тенденції розвитку технології тієї чи іншої галузі;

- основи управління персоналом (у тому числі - наукову організацію праці, психологію керування, конорліктологію);

- застосування в менеджменті інформаційних технологій;

- основи управління якістю;

- статистичну звітність і бухгалтерський облік.

Менеджер з КСВ повинен творчо підходити до роботи та намагатися змінити світ на краще. Адже принципи КСВ спрямовані на інтереси людей та планети в цілому, цією профресією здебільшого займаються жінки в Україні - 80\%, в світі - 60\% [3]. На даний момент в Україні дипломованих фахівців у сфері корпоративної соціальної відповідальності немає. В основному це перекваліфріковані працівники прес-служби або департаменту корпоративних комунікацій. Навчання або перепідготовку менеджерів з КСВ здійснює Центр «Розвитку КСВ», який з 2008 року започаткував свою діяльність, і 3 того часу допомагає підприємствам розробити довгострокові стратегії 3 КСВ та навчає фрормувати нефрінансові звіти у яких підприємства відображають свою соціальну діяльність та ін.

Менеджер з КСВ повинен знати та виконувати обов'язки, основні з яких [13]:

- розробка стратегій, планів та проектів 3 корпоративної соціальної відповідальності, показники есрективності, а також відстеження їхньої реалізації та звітування;

- підготовка щорічних звітів з корпоративної соціальної відповідальності;

- створення системи управління КСВ в компанії;

- проведення досліджень, розбудова відносин зі стейкхолдерами (партнерами, клієнтами, громадськими організаціями), координація активностей, які матимуть позитивний вплив на довкілля та місцеві спільноти;

- підвищення обізнаності про КСВ компанії і робота з партнерами.

На нашу думку, менеджер з корпоративної соціальної відповідальності - це управлінець, який визначає та координує роботу, спрямовану на реалізацію суспільно орієнтованих програм, приймає рішення та несе відповідальність за їх інтеграцію у виробничо-економічну діяльність підприємства. 
У міжнародному стандарті ISO 26000: 2010 «Керівництво 3 соціальної відповідальності» прописані принципи соціальної відповідальності, а саме: підзвітність, прозорість, етична поведінка, повага інтересів зацікавлених сторін; дотримання верховенства закону, міжнародних норм поведінки та прав людини. Згідно з цими стандартом менеджера з корпоративної соціальної відповідальності повинен підтримування позитивні ділові взаємовідносини з працівниками компанії, державою, соціальними громадами та стейкхолдерами.

Європейська асоціація професіоналів 3 питань сталого розвитку за підтримки KPMG та GreenFlex провела дослідженні у якому взяли участь 186 респондентів з Італії, Франції, Німеччини, Іспанії, Сербії, Туреччини та Великобританії. Аналізуючи результати досліджень Марини Гриценко про профресію менеджерів 3 КСВ та сталого розвитку можна виділити [14]:

- у Європі підрозділи з КСВ у середньому складається 3 двох осіб;

- 34,2\% КСВ-менеджерів підпорядковуються департаменту комунікацій, а 15,3\% HR-департаменту;

- 47,3\% професіоналів займають посаду під назвою «Менеджер з КСВ»;

- осріційно 46,8\% менеджерів з КСВ залучені до стратегічного планування, а 37,6\% неофріційно;

- КСВ менеджер у країнах Європи - це у більшості випадків жінка віком 31-50 років, 3 досвідом від 2 до 10 років роботи у цій сфері;

- більшість менеджерів з КСВ та сталого розвитку входять до складу підрозділів, які відповідають за комунікації - 34,2\%; HR-16,2 \%; якість - 5,4\%; стратегічний розвиток - 4,5\%; внутрішній аудит - 5,4\%; та інші;

- заробітна плата у різних країнах нерівномірна. Середній рівень коливається в межах від 50 тис. до 100 тис. євро на рік.

Проаналізовано дві готельні мережі Hilton Hotels \& Resorts та Radisson Hotel Group $3 а$ напрямами соціальних проєктів, та фрахівців які їх розробляють, координують та звітують про якість проведення заходів. Дослідження показало, що немає фрахівця з КСВ у готелі Radisson Hotel Group, а в готелі Hilton Hotels \& Resorts $€$ створений відділ корпоративної відповідальності. Цей відділ відповідає за стратегію корпоративної відповідальності компанії „Travel with Purpose” та зовнішні комунікації. Радою директорів було створено комітет Nominating \& ESG Committee of the Board. У Статуті даного Комітету у 17 пункт і чітко визначені його фрункції щодо корпоративної відповідальності у компанії: “Для виконання Компанією своєї програми з відповідальності перед суспільством в цілому, має періодично переглядати та оцінювати стратегію, практику та політику корпоративної відповідальності i, за необхідності, робити рекомендації Раді Директорів щодо них" [15].

Спільним проєктом мережі готелів Hilton 3 американською екологічною ініціативою Clean the World, проводиться переробка залишків мила з номерів готелів. Нові шматки мила вже було поширено в кількості $44 \mathrm{Mлн}$ шт. в 127 країн з низьким рівнем гігієни. На зборах Ради директорів Hilton щоквартально проводиться огляд досягнень у поставлених цілях по всіх проєктах КСВ до 2030 року. Компанія планує досягти нульових відходів мила, а також збереження ресурсів за рахунок скорочення викидів вуглецю; економне використання води; розробка послідовної методології для вимірювання харчових відходів; заохочення постачальників готельної мережі до встановлення власних екологічних та соціальних цілей; збереження прав людини та ін. [16]. Компанія подає щорічний звіт КСВ, а також бере участь в опитуваннях та рейтингових індексах щодо впливу на навколишнє середовище, а саме Індекс стійкості Доу Джонса, CDP, ISS ESG, MSCI тa Sustainalytics.

Готель Park Inn by Radisson Kyiv Troyitska у Києві, Radisson Blu в Буковелі та Radisson Hotel City Centre Odessa на Дерибасівській в Одесі належать до міжнародної мережі Radisson Hotel Group. Мають розроблений свій індивідуальний план програм «Відповідальний бізнес», де КСВ діє у трьох основних напрямках: think planet (думаю про планету); think people (думаю про людей); think together (думати разом).

У готелях діє програма Blu planet за якою випроваджено новітні технології та установок по фрільтрації та очищенні води, яка дає можливість скоротити її використання приблизно на $25 \%$ в рік. Radisson Blu Hotel, Kyiv долучився до міжнародної акції Walk for Water, де керівництво готелю пожертвувало значну суму міжнародному благодійному фонд Just A Drop на допомогу людям, які страждають від нестачі питної води. А також готель підтримує велику кількість благодійні акції. «Здай кров - врятуй життя», яка проходить у готеляx Radisson Blu 3 метою популяризації донорства крові в Україні. «Be Pink in a Pink October» всесвітня акція проти раку молочної залози. Radisson Blu Hotels проводить спеціальний "Рожевий сніданок" для підвищення 
обізнаності щодо профрілактики раку молочної залози. Готель $є$ офріційною точкою збору батарейок 3 метою їх безпечної утилізації у рамках проєкту Green Key. До «Дня вишиванки» всі працівники готелів вбираються у етнічні українські вбрання розповідаючи гостям готелю про цікаві фракти української культури та традиційний одяг українців. Керівництво готелів дбає про розвиток персоналу проводячи навчальні професійні програми та тренінги [17]. Генеральний менеджер готелю відповідає за стратегію корпоративної відповідальності компанії, HR-менеджер інфрормує працівників компанії про те, які програми КСВ запущені.

Отже, аналізуючи КСВ у сфрері послуг, підприємства намагаються активно впроваджувати принципи КСВ, головними $є$ екологічні програми та проєкти по збереженню довкілля, значна увага приділяється навчанню та здоров'ю працівників.

Висновок. Концепція соціально відповідального бізнесу набула глобальних масштабів у всьому світі. Добровільне залучення срінансів та ресурсів підприємства для реалізації соціальних програм це міжнародний тренд. Соціальний проєкт це своєрідна послуга, яка повинна пройти певні етапи, а саме визначення цільової групи, планування проєкту, реалізація, контроль, аналіз кінцевих результатів та звіт перед керівництвом підприємства, працівниками, стейкхолдерами, суспільством, а отже ці всі етапи повинна здійснювати одна відповідальна людина, а саме менеджер 3 КСВ. Досвід показує, що підприємства можуть реалізовувати свої соціальні програми та бути прибутковими одночасно, якщо цими питанням займається менеджер з КСВ.

\section{СПИСОК ВИКОРИСТАНИХ ДЖЕРЕЛ:}

1. Bowen H. Social responsibilities of the businessman. New York: Harper \& Row, 1953. 285 p.

2. Friedman M. The Social Responsibility of Business is to increase its Profit. New York Times Magazine. 1970. September, 13. P. 122-126.

3. Davis K. The case for and against business assumption of social responsibilities. Academy of Management Journal. 1973. Vol. 16(2). P. 313-321.

4. Carroll A.B. The pyramid of corporate social responsibility: oward the moral management of organization stakeholders. Business Horizons. 1991. Vol. 34(4). P. 42.

5. Баюра Д.О. Організаційно-економічний механізм управління корпоративною соціальною відповідальністю в умовах глобалізації. Теория и практика управления. 2012. № 1. С. 65-69.

6. Березіна О.Ю. Теоретичні підходи до визначення поняття «корпоративна соціальна відповідальність». Житомир : ЖДТУ, 2010. С. 223-225.

7. Поважний О.С., Орлова Н.С. Формування корпоративної стратегії на основі соціальної відповідальності. ДонДУУ : «Менеджер», 2014. С. 4-10.

8. Олійник О.О. Соціальна відповідальність : навч. посіб. Рівне : НУВГП, 2016. 222 с.

9. Зінченко А.Г., Саприкіна М.А. Корпоративна соціальна відповідальність 2005-2010: стан та перспективи розвитку. Київ : Вид-во «Фарбований лист», 2010. 56 с.

10. Іваницька О.М., Іваницький О.В. Регулювання процесів запровадження соціальної відповідальності бізнесу: досвід розвинених країн та уроки для України. Стратегія розвитку України. 2015. № 2. С. 23-28.

11. ISO. ORG. URL: https://www.iso.org/iso-26000-social-responsibility.html (дата звернення: 15.09.2021).

12. PROFORIENTATOR.INFO. URL: http://proforientator.info/?page_id=4945 (дата звернення: 15.09.2021).

13. Rabota.ua. URL: https://prohr.rabota.ua/ksv-menedzher-ka-portret-profesiyi-cheyndzhmeykera-ta-top-6viklikiv/ (дата звернення: 15.09.2021).

14. Happy Monday. URL: https://happymonday.ua/ru/hto-taki-menedzhery-korporatyvnoyi-sotsialnoyividpovidalnosti-ta-stalogo-rozvytku-v-yevropi (дата звернення: 15.09.2021).

15. Статут Ради директорів компанії Хілтон. URL: https://ir.hilton.com/ /media/Files/H/HiltonWorldwide-IR-V3/ committee-composition/nominating-and-esg-committee-charter-2020-final.pdf (дата звернення: 15.09.2021).

16. Звіт з КСВ компанії Хілтон за 2020 рік. URL: https://cr.hilton.com/wp-content/uploads/2021/04/Hilton-2020ESG-Report.pdf (дата звернення: 15.09.2021).

17. Paragraf - accelerator of social changes. URL: http://www.prgrf.com/bss-18-05/ (дата звернення: 15.09.2021).

\section{REFERENCES:}

1. Bowen H. (1953) Social responsibilities of the businessman. New York: Harper \& Row, p. 285. 
2. Friedman M. (1970) The Social Responsibility of Business is to increase its Profit. New York Times Magazine. September, 13, pp. 122-126.

3. Davis K. (1973) The case for and against business assumption of social responsibilities. Academy of Management Journal, vol. 16(2), pp. 313-321.

4. Kerroll A.B. (1991) Piramida korporatyvnoyi sotsialnoyi vidpovidalnosti: moralne upravlinnya zatsikavlenymy storonamy orhanizatsiyi. Business Horizons, vol. 34(4), p. 42.

5. Bayura D.O. (2012) Orhanizatsiyno-ekonomichnyy mekhanizm upravlinnya korporatyvnoyu sotsialnoyu vidpovidalnistyu v umovakh hlobalizatsiyi. Teoryya y praktyka upravlenyya, no. 1, pp. 65-69.

6. Berezina O.Y. (2010) Teoretychni pidkhody do vyznachennya ponyattya «korporatyvna sotsialna vidpovidalnist». Zhytomyr: ZHDTU, pp. 223-225.

7. Povazhnyy O.S., Orlova N.S. (2014) Formuvannya korporatyvnoyi stratehiyi na osnovi sotsialnoyi vidpovidalnosti. DonDUU: «Menedzher», pp. 4-10.

8. Oliynyk O.O. (2016) Sotsialna vidpovidalnist: navch. posib. Rivne: NUVHP, 222 p.

9. Zinchenko A.H., Saprykina M.A. (2010) Korporatyvna sotsialna vidpovidalnist 2005-2010: stan ta perspektyvy rozvytku. Kyiv: Vyd-vo «Farbovanyy lyst», $56 \mathrm{p}$.

10. Ivanytska O.M., Ivanytskyy O.V. (2015) Rehulyuvannya protsesiv zaprovadzhennya sotsialnoyi vidpovidalnosti biznesu: dosvid rozvynenykh krayin ta uroky dlya Ukrayiny. Stratehiya rozvytku Ukrayiny, no. 2, pp. 23-28.

11. ISO. ORG. Retrieved from: https://www.iso.org/iso-26000-social-responsibility.html

12. PROFORIENTATOR.INFO. Retrieved from: http://proforientator.info/?page_id $=4945$

13.Rabota.ua. Retrieved from: https://prohr.rabota.ua/ksv-menedzher-ka-portret-profesiyi-cheyndzhmeykera-tatop-6-viklikiv/

14. Happy Monday. Retrieved from: https://happymonday.ua/ru/hto-taki-menedzhery-korporatyvnoyi-sotsialnoyi-vidpovidalnosti-ta-stalogo-rozvytku-v-yevropi

15. Statut Radi dyrektoriv kompaniyi Khilton. Retrieved from: https://ir.hilton.com/ /media/Files/H/HiltonWorldwide-IR-V3/comCommittee-composition/nomination-and-esg-com Committee-charter-2020-final.pdf

16. Zvit z KSV kompaniyi Khilton za 2020 rik. Retrieved from: https://cr.hilton.com/wp-content/uploads/2021/04/ Hilton-2020-ESG-Report.pdf

17. Paragraf - accelerator of social changes. Retrieved from: http://www.prgrf.com/bss-18-05/ 